\title{
IMPLEMENTATION OF TELKOM COMPANY PARTNERSHIP PROGRAM IN THE SME EMPOWERMENT FRAMEWORK
}

\author{
Masruddin, Rahayu Indriasari, and Jurana \\ Economic Faculty, Tadulako University, Palu, Indonesia
}

\begin{abstract}
This study aims to find out in depth the procedure of implementation of partnership program conducted by Telkom company in order to empower SME (Small and Medium Enterprises) in Palu city of Central Sulawesi, Indonesia. In addition, this study investigate to how the influence of the implementation of partnership programs on the power of SMEs that become partners. This study used a qualitative approach in the realm of interpreative paradigm. The research method used to collect and analyze data is by observation and direct interview in Telkom company branch of Palu. The results of this study indicate that the existence of this partnership program, some people in the city of Palu who know the program feel very helpful. There are several weaknesses and obstacles encountered in the implementation of this partnership program, among others: first, CDC Unit has not been fully able to analyze the proposal from prospective partner of Telkom company. Secondly, the absence of financial records of SMEs, so that SMEs are difficult to know and determine the turnover of its business. Third is the lack of effective coaching is done, because coaching is only done before the signing of the contract (initial crediting), not intensified by Telkom during the contract runs. Fourthly, there is still no transparency from Telkom related to the prospective partners who were accepted and rejected even though they have met the requirements. This resulted in the presupposition of the prospective partners assisted by the existence of the lack of independence from Telkom. Fifth, the implementation of $5 \mathrm{C}$ in the partnership program has not run optimally, this is also due to the lack of employees who handle it optimally. Sixthly, there are still partners who are less serious by utilizing the facilities provided by Telkom company partnership program.

Keywords: Partnership Program, SME Empowerment, Telkom company Palu
\end{abstract}

\section{INTRODUCTION}

The development of entrepreneurship, especially SME (Small and Medium Enterprises) is seen as a strategic step in the effort to help overcome the economic problems of the Indonesian nation. Various efforts have been made by the government in developing and advancing SMEs in Indonesia. One of them is by issuing law no. 19/2003 article 2 concerning SOEs explaining one of the intentions and objectives of the establishment of SOE (state-owned enterprises) is to actively provide guidance and assistance to entrepreneurs of economically weak, cooperative, and community groups, and its form is the implementation of PKBL (Partnership and Community Development Program) by all SOE including in it PT. TELKOM.

The partnership program is a revolving fund distribution program derived from a portion of the company's profits, and is channeled to SMEs in addition to its business capital in shortterm loans. The revolving fund channeling program is an obligation for SOEs based on laws aimed at improving the ability of small and medium enterprises to enable SMEs to be self-reliant, 
tough and expand into larger medium-sized enterprises. Partnership program at PT. Telkom branch of Palu has been started in the second quarter of 2003. During 2015 PT. business sectors. Until 2015 revolving funds that have been distributed by PT. Telkom branch of Palu has reached Rp. 30 billion with the number of partners assisted by more than 1,000 partners (MB).

Problems found in PT. Telkom related to the channeling of revolving funds in the partnership program, which is less precise the implementation model and the target of channeling of revolving funds that can cause bad loans at the repayment stage of the loan. Total bad loans from 2003 to 2010 amounted to IDR 2,272,355,512, -. The number of partners in arrears from 2003 to 2010 is 209 partners. Basically, the role of SOE including PT. Telkom in the empowerment of SMEs not only consists of providing assistance, but also coaching. Guidance that includes the provision of understanding and also the provision of skills to SMEs in managing business funds. This is in accordance with Act no. 19/2003 Article 2 mentioned above. However, the CDC (Community Development Center) unit as the implementing unit of the partnership program is seen to be more focused on providing assistance only, whereas in the case of coaching has not been implemented optimally.

Based on the Law of the Republic of Indonesia Number 19 Year 2003 regarding State Owned Enterprises, regarding the provision of business capital assistance and coaching by SOE to small and medium enterprises. This program is a very noble program, but on the other hand some of the partners do not run the trust given through the loaned refund so that bad credit from the program to Telkom company reached $10 \%$ to $15 \%$. Partnership condition of PT. Telkom and small-medium enterprises is what causes the authors are interested to conduct this research. Therefore, this study aims to understand and know in depth the implementation of partnership program at PT. Telkom branch of Palu.

\section{LITERATURE REVIEW}

\section{SOE Partnership Program}

Partnership program is one of the programs held by every SOE. This program is a revolving fund distribution program, which provides additional business capital for SMEs with the terms, procedures and time of return that has been established and agreed by both parties. Kaniawati, Lilyana, dan Rijayana (2016) said that through the implementation of this partnership program, SMEs that become partners of PT. Pertamina can be said to grow and also have the confidence to follow the competition in the global market. However, the implementation of this partnership program should be accompanied by continuous guidance and supervision so that the objectives of the program can be achieved.

According to Rudiantoro \& Siregar (2011) basically SMEs who become respondents in his research understand that financial bookkeeping and reporting is important enough in the growth and development of business, but less understood in the process of preparation of bookkeeping. Therefore, this is a separate task for SOEs to conduct training on the preparation of financial statements for SMEs who become partners. Thus, during the implementation of partnership programs by SOEs, especially PT. Telkom has not been maximized in terms of guidance and supervision to its partner, so that empowerment efforts are not maximal yet. Therefore, it is necessary to model the implementation of the partnership program in an effort to empower the partners built, so that the desired expectations can be achieved, and the government's goals are done well.

\section{SME empowerment}

Empowerment as a translation of the Merrian Webster empowerment in the Oxford English Dictionary contains two meanings: 1) To give ability or enable to, which is translated as giving abilities / abilities or enabling. 2) Togive power of authority to, which means giving 
power. Carlzon and Macauley, as quoted by Sadu (1998, hlm. 46) argue that empowerment is "to free a person from rigid control, and to give people freedom to take responsibility for his ideas, his decisions and his actions". So empowerment is basically making things have power.

Law No. 9 of 1995 on Small Business explicitly states the purpose of empowering small businesses are as follows: 1) Growing and improving the ability of small-scale enterprises to be a strong and independent business and can develop into medium-sized businesses. 2) Increasing the role of small-scale enterprises in the formation of national products, the expansion of employment and business opportunities, the increase of exports, as well as the increase and distribution of revenues to realize itself as the backbone and strengthen the structure of the national economy in order to achieve the goal of empowering small businesses.

The role and duties of the government in the empowerment of small businesses according to Law No. 9 of 1995 concerning Small Business include: 1) Growing a conducive business climate for small businesses through the establishment of legislation and financing policies, competition, infrastructure, information, partnerships, effort and protection. 2) Conducting coaching and small business development together with the business world and society especially in the field of production and processing, marketing, human resources and technology. 3) Provide financing for small business empowerment together with business world and community in the form of bank credit, non-bank financial institution loan, venture capital, loan from provision of part of SOE profit, grant and other type of enrichment. 4) Facilitating small business partnerships with medium and large enterprises through the core patterns of plasma, sub contracts, general trading, franchising, agency, and other forms of partnership. 5) Assign Ministers in charge of small businesses to coordinate and control the empowerment of small businesses. 6) Implement criminal and administrative sanctions to medium and large enterprises that are detrimental to the empowerment of small businesses.

Small businesses that have been fostered and developed into medium-sized businesses can still be given guidance and development period of maximum of three years, and still can occupy the business location and conduct business activities that are reserved. The Government determines the areas of coaching and development that still need to be provided to medium-sized enterprises. Meanwhile, during this coaching provided to the partners are not so maximal, so often the working capital provided is not well processed. This has resulted in the partners being unable to repay the loan obtained in accordance with the agreed agreement (bad credit). Bad credit that happened at PT. Telkom Palu branch from 2003 to 2010 amounted to Idr 2.272.355.512, -. The number of partners experiencing bad loans from 2003 to 2010 is 209 partners. Therefore, this research is very important to do in the hope of obtaining a model implementation of the implementation of a partnership program that is suitable to be applied in PT. Telkom Branch Palu.

\section{RESEARCH METHODS}

To know and understand in depth about the implementation of partnership program at PT. Telkom branch of Palu. Method of collecting and analyzing data is done by using interview and observation directly in Telkom company Palu Branch. This study was conducted for 8 months. The key informant in this research is RF who is the officer who handles the partnership program of Telkom company Palu Branch.

According to Moustakas (1994) the principles of phenomenology research can be elaborated in the form of four stages of research data collection, which consists of: 1) research planning stage which includes the activity of making a list of questions, explaining the background research, selecting informants and document review. 2) Data collection phase, in this stage of in-depth interview activity is the main key because with this method the essence of the 
observed phenomenon. 3) Data analysis phase, at this stage Moustakas (1994) divides the above activities; horizonalizing the data obtained, list meaning, grouping in certain themes, making textual descriptions or descriptions, creating structural descriptions. 4) The last stage is to make conclusions, contributions and research benefits. To carry out phenomenological research phases, a circular procedure of data collection from Creswell (1998, hlm. 65) was applied. Through this method, researchers can understand and know in depth about the implementation of the partnership program that has been running.

\section{RESULT AND DISCUSSION}

PT Telekomunikasi Indonesia, Tbk. hereinafter referred to as TELKOM, is the largest provider of information and telecommunication services (InfoComm) as well as the largest full service and network provider in Indonesia. PT. Telkom conducts business transformation through a number of other stages, including business development aimed at accommodating customer needs and exploring opportunities. Telecommunications as an integrated operator, PT. Telkom has been engaged in business development based on fixed wireline, fixed wireless, cellular, data and internet and network \& interconnection services to meet the needs of various customer segments, both regular customers, corporate customers, and other licensed telecommunication operators.

In addition, related to Partnership Program, there are corporate support activities that are CSR or Corporate Social Responsibility. PT. Telkom conducts activities that are social as the company's responsibility to the environment. Responsible for the implementation of these activities is the CDC Unit or Community Development Center.

PT Telekomunikasi Indonesia, Tbk (TELKOM) is one of the State-Owned Enterprises committed to performing the role of Good Corporate Citizenship through the implementation of Partnership Program with small business and Community Development Program. The Partnership program with small business aims to encourage economic activity and growth, creation of employment opportunities and opportunities for the community. While the Community Development Program has a goal to empower and develop the social conditions of society and the environment around the business area of the Company.

\section{Implementation of Partnership Program PT. Telkom Indonesia (Persero) Tbk Palu Branch}

Partnership and Community Development program activities in Telkom company is a form of social responsibility (CSR) to the community around the company. This form of activity can contribute to improving the company's image in the community and the environment around the company. The purpose of doing is for the existence of the company can be received well and can give a positive contribution to the business development of PT. Telkom. Although the initial formation of this program is the idea of internal employees of Telkom company. This was disclosed by RF as the officer handling partnership program Telkom company Palu branch.

"It's some kind of CSR. In the past ... the loan funds, d take from telkom employees set aside as loan money for who needs. so it was taken from the gratuity of employees, cuman employees now do not want. If this new rule, the money is from Telkom's percent of income". (RF Expression)

The person in charge of implementing this partnership program is the Community Development Center (CDC) unit. This CDC unit has been in existence since September 2003. The purpose of the establishment of this CDC unit is to assist the company in fulfilling and realizing its social responsibility or that we often know with Corporate Social Responsibility (CSR) as one of the big companies in Indonesia. The activities of this partnership program each year continue to increase both in terms of nominal amount of aid, lending and receiving of installments. In the year 2015 yesterday PT. Telkom has channeled more than 2.6 billion 
revolving funds to 96 partners assisted in various business sectors. Until 2015 revolving funds that have been distributed by PT. Telkom branch of Palu has reached Rp. 30 billion with the number of partners assisted by more than 1,000 partners (MB). Meanwhile, Human Resource Manager of Telkom Sulteng Sahran Talasari said the total realization of channeling of Telkom revolving fund during 2016 has reached more than Rp 3 billion. The number includes 102 partners from various fields of industry, services and trade.

Funds distributed as a revolving fund in the partnership program came from $2 \%$ of the company's total profits or profits, which then distributed the seven regional divisions in accordance with the proposed budget of each regional division (Fitria dan Jurana, 2015). Fitria and Jurana also revealed that the distribution of Partnership and Community Development (PKBL) assistance since 2010 has been gradually directed to activities related to the field of ICT (Information and Communications Technologies). This is done because PT. Telkom is aware of the great potential of the SME (Small Medium Enterprise) business sector in supporting Indonesia's economy, although it has not yet fully gained a touch of information technology.

Partnership program of PT. Telkom Branch Palu is devoted to help increase business capital in Small and Medium Enterprises, rather than providing initial capital. This is certainly in accordance with the mission of the establishment of developing SMEs. Therefore, one of the requirements of filing as partner built by PT. Telkom is the minimum business age of 1 (one) year. The term of this rolling refund is 24 months or 2 (two) years with interest of $6 \%$ every year. The interest rate is lower than the interest rate on the bank. The built partner can repay the revolving funds before maturity with a proportional interest. If the assisted partner completes the loan repayment over the maturity date, the assisted partner must only complete the rest in the sense that there is no additional interest for late payment. At the time of repayment even the assisted partner can immediately take the collateral that is guaranteed without having to wait for days with complicated procedures. Number of tolerance given by PT. Telkom makes the high interest of SMEs to partner with Telkom company. However, in this case many SMEs do not know the partnership program at PT.Telkom. Most SMEs only know the bank as a party that can help in increasing their business capital.

Collateral-shaped certificate that became the guarantee partner of PT. Telkom will become the property of PT. Telkom if the partners are unable to repay the revolving fund, which will be auctioned at the center of Regional Division 7 (seven) or East Indonesia, Makassar. The proceeds from the auction will be used to repay the partner's rolling funds in arrears and if there is any remnant then returned to the partner. However, things like this are rare because PT. Telkom will thoroughly review the condition of the assisted partners not returning the revolving fund. In fact, not infrequently, if in fact the partner assisted by a disaster and business bankruptcy then the interest will be abolished and only return the principal with an extension of time in accordance with the policy provided by PT. Telkom. This is done to the assisted partners who get loan assistance above 20 million. Generally, the partner of Telkom company Palu chooses loan assistance of less than or equal to 20 million, because this loan does not require grant. This was revealed by the researcher's informant:

"SMEs choose more loans under 20 million because they if the loan under 20 million is not used at all".

The various terms and conditions of credit loans from PT. Telkom branch of Palu is: first, to become a partnership partner, then the business trip exceeds one year, the status of business location is private property, and if the status of the lease must attach the lease certificate, obtain approval from husband / wife or parents if not married, a recommendation from the RW or $\mathrm{RT}$, is not getting help from another party, the asset must not exceed two hundred million, a turnover of less than a hundred million, owns immovable collateral if the loan exceeds twenty 
million, records of financial information for the past three months, residents, family cards, photos of business activities, floor plans and residence, and domicile certificate. Meanwhile, for businesses with legal status, they must attach additional requirements such as: business establishment certificate, business register, business license, and taxpayer ID. Second, the credit terms set forth in the partnership program are: the maximum credit limit for newly established partners is ten million, the maximum credit limit of fifty million rupiah, the interest rate set at six per cent per annum, the maximum loan term of twenty four months, If the settlement before the due date, then the calculation is done by way of deposit. The system and procedures for the implementation of partnership program pt. Telkom branch of Hammer contained in the following picture : (Source: CDC PT. Telkom Branch Palu)

\section{Implementation System Partnership Program PT Telkom Palu Branch}

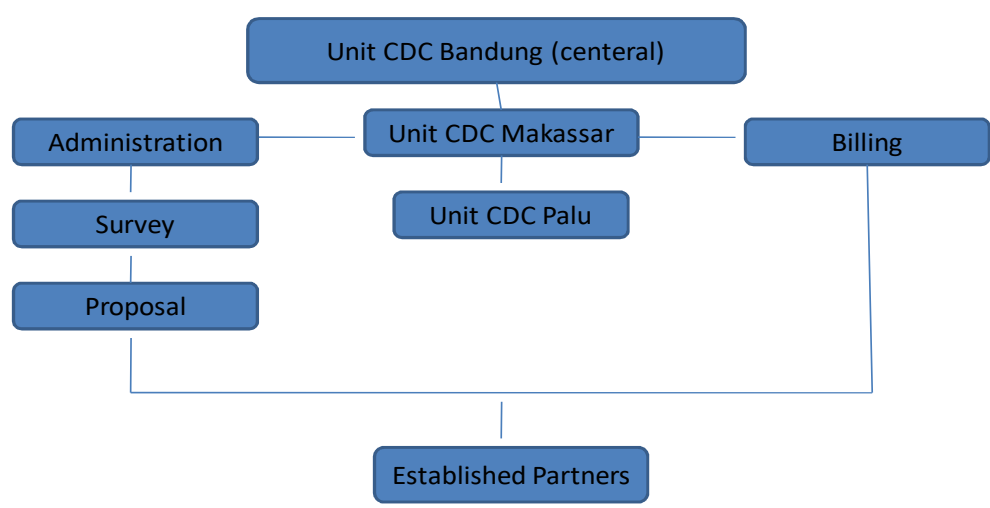

Source: CDC PT. Telkom Branch Palu

The implementation system of Telkom company partnership program is done by: prospective partners to submit proposal proposal for fund assistance to CDC unit PT. Telkom. The CDC unit then analyzes the proposal. then the CDC unit surveys the efforts of prospective partners. If after the survey of potential partners are eligible and in accordance with existing provisions, then the submission will be approved. After that will be determined the amount to be given in accordance with the results of analysis and survey. Furthermore, the CDC will send the submission to the CDC unit of Makassar in the quarter. Then CDC forward it to CDC Bandung unit (Centeral). Upon approval of CDC unit Bandung, CDC unit PT. Telkom Palu conducts cooperation contracts with the partner assisted while conducting debriefing. The CDC Bandung unit then transferred to the partner accounts without going through the CDC Palu unit. Payment of monthly revolving funds is paid directly to Telkom company Palu branch account. Total amount of total payment result every month transferred to CDC unit Bandung.

Representatives of Telkom company's partners will be participated in the exhibition held by PT. Telkom as an effort to help promote the efforts of partners and promote CSR that has been done by Telkom company to the surrounding environment. The participants will be selected in 
The International Journal of Accounting and Business Society 59 accordance with the eligibility and uniqueness of their business, following the selection of the target band to be included in the exhibition:

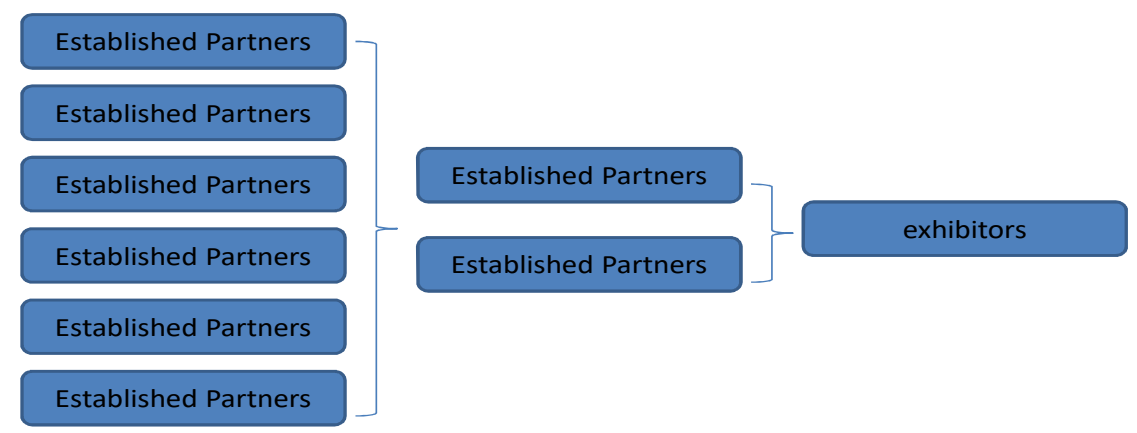

Source: CDC PT. Telkom Branch Palu

\section{Picture of Exhibitor Selection Flow}

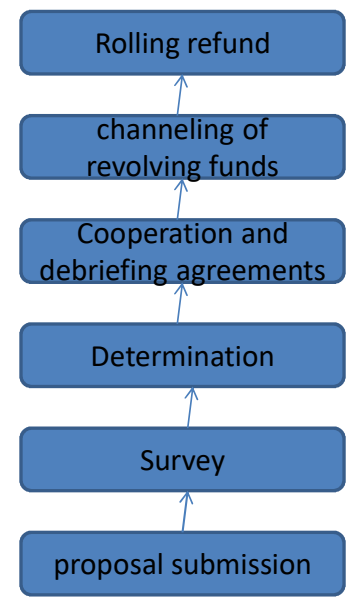

Source: CDC PT. Telkom Branch Palu

Picture of Partnership Program Implementation Procedure 


\section{C Implementation In Partnership Program PT. Telkom Branch Palu}

Loan disbursements by companies generally follow the principle of lending to banks. The guidelines or the principle of credit disbursement that consists of Character, Capability, Capacity, Condition of economic, and Cholateral or better known as Five Principle of Credit (5C). Likewise that happened at PT. Telkom that uses the $5 \mathrm{C}$ guidance in order to get the confidence of PT. Telkom as the creditor to the prospective debtor.

Before issuing the decision of the prospective borrower or prospective partner who will be a potential assistant, the CDC Unit as the implementer of the partnership program conducts a survey on potential partners based on the $5 \mathrm{C}$ principle. The following $5 \mathrm{C}$ details are used by the CDC unit during the survey: (1) Character, with indicators of social behavior, religious life, and personality. (2) Capability, with indicators of organizational ability, entrepreneurship ability, marketing ability, and financial management capability. (3) Capacity, with indicators of ease of obtaining raw materials, fairness of prices, experts, equipment usage, and profit and loss projections. (4) Condition Of Economic, with indicators Employee Recruitment, benefits for the community, and marketing analysis. (5) Cholateral, with indicator of the existence of deed of establishment of company, Certificate of Company Registration (TDP / TDUP), Trading Business License (SIUP), Taxpayer Identification Number (NPWP), Determination of Taxable Entrepreneur (PKP), Family Card and KTP Husband / Wife, Certificate of domicile, Recommendation of RT / RW, Letter of contract / residence lease, and Warranty (for grant).

Review of Partnership Program Implementation of PT. Telkom Branch Palu Based on the results of interviews with partnership program officers in Telkom company Palu branch, obtained the view of Telkom company related to SMEs or prospective partners assisted in fulfilling the terms and conditions in this activity are: First, that for SMEs understanding in the preparation of financial statements. Secondly, the absence of financial records of SMEs, so that SMEs are difficult to know and determine the turnover of its business. Both of these are expressed by RF informants, namely:

"Most of the targeted do not want to provide such terms as financial statements. They want to sign (stands for signature) and in love of the loan. Do not want to be bothered and .... because they say, if in the bank we stay signed and in the fill".

Meanwhile, from the fist of researchers based on the implementation procedures of partnership program of PT. Telkom Palu there are several weaknesses and obstacles encountered namely: first, CDC Unit has not been fully able to analyze proposal submission from prospective partner built by Telkom company. This is known after viewing the proposal file of potential partners. In the proposal file, there is still a form of financial statements that are not filled completely, so as not to provide detailed information related to the financial condition of SMEs. Second, the financial report format prepared by the CDC unit (intended to make it easier for SMEs in the preparation of financial statements) can not be functioned well by SMEs due to various factors, including the limitations and lack of understanding of SMEs, and the seriousness of SMEs. This is based on the expression of the RF informant:

"If the partners are viewed from the level of education banya also the only graduate smp, sd mergers can directly fill the format. Even S1 or d3, they say how this, how it is. So it might be his willingness. Level of seriousness".

The third constraint is the ineffectiveness of the guidance that is done, because the guidance is only prior to the contract signing (early crediting), not intensified by the telkom during the contract. This happens due to the limited number of employees who are competent in the field and specifically handle the function tersebut.Here RF exposure related to this matter: 
"Well, that's it ... there should be a part that should be special in coaching. who can bolt them. so there are three really important parts. Only there is one who holds the responsibility for everything. So sometimes there are terabaiakan because usually all that, deadlines. Kayak for example we have exhibition preparation. So this month we focus on exhibition. Whereas if so, we do not control again the return of partners ka .... this already paid or not ... because no one menghendel, so half dead because we everything".

Fourthly, there is still no transparency from telecom related to the prospective partners who were accepted and rejected even though they have met the requirements. This resulted in the presupposition of the prospective partners assisted by the existence of the lack of independence from Telkom. Therefore it is advisable to build an online system to perform and smoothen this partnership program.

Fifth, the implementation of $5 \mathrm{C}$ in the partnership program has not run optimally, this is also due to the lack of employees who handle it optimally. Sixth, there are still many less serious partners built by the proper functioning of facilities provided by Telkom company's partnership program.

\section{CONCLUSION}

Based on the results of interviews and direct observation with RF related to the implementation of partnership program of PT. Telkom obtained data that with this partnership program, some people in Palu city who know the program feel very helpful. The low interest rates charged to the assisted partners, although the funds lent are limited.

There are several weaknesses and obstacles faced in the implementation of this partnership program, among others: first, the CDC Unit has not been fully able to analyze proposals submitted from prospective partners of Telkom company. Secondly, the absence of financial records of SMEs, so that SMEs are difficult to know and determine the turnover of its business. Third is the lack of effective coaching is done, because coaching only do before the signing of the contract only (early lending), not done intensely by Telkom company during the contract runs. Fourthly, there is still no transparency from the telecom related to the prospective partners who were accepted and rejected even though they have met the requirements. This resulted in the presupposition of the prospective partners assisted by the existence of the lack of independence from Telkom. Therefore it is advisable to build an online system to perform and smoothen this partnership program. Fifth, the implementation of $5 \mathrm{C}$ in the partnership program has not run optimally, this is also due to the lack of employees who handle it optimally. Sixthly, there are still partners who are less serious by utilizing the facilities provided by Telkom company partnership program. 


\section{REFERENCES}

Creswell, J. 1998. Qualitative Inquiry and Research Design, Choosing Among Five Traditions (Translator.). California: Sage Publication.

Department of Trade. 2008. Creative Economy Development 2025 - Creative Economy Development Plan 2009-2015. Working Group of Indonesia Design Power Ministry of Trade Republic of Indonesia.

Dinas Perindagkop and UMKM of Palu City. 2013. MSME data in Palu City.

Dwita Yuniar. 2013. The Effect of People's Business Credit (KUR) to Income and Employment Opportunities of Micro Small and Medium Enterprises (UMKM) (Study at Bank Rakyat Indonesia Jogis Unit Yogyakara). Essay. S1-State University of Yogyakarta

Fitria, R., \& Jurana. 2015. Implementation Analysis of Partnership Program for SME Empowerment (Case Study of Partnership Program of TELKOM COMPANY Palu Branch of Central Sulawesi). Journal of Business and Islamic Management, 3 (2).

Kaniawati, K., Lilyana, F., \& Rijayana, I. 2016. Analysis of Credit Disbursement on SME Development Through Partnership Program and Community Development PT Pertamina (Persero) Marketing III Bandung Branch. National Seminar on the Implementation of Research and Community Service III 2016, 286-300.

Moustakas, C. 1994. Phenomenological Reaserch Methods (Translator). California: Sage Publications

Rudiantoro, R., \& Siregar, V. S. 2011. Quality of MSME Financial Statement and Prospect of Implementation of SAK ETAP. Symposium National Accounting XIV.

Sadu, W. 1998. Regional Apparatus Empowerment (Translator, Trans.). Bandung: Abdi Praja. 